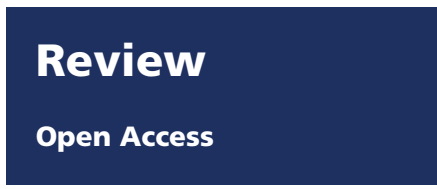

\title{
The significance of beige and brown fat in humans
}

\section{Florian W Kiefer}

Clinical Division of Endocrinology and Metabolism, Department of Medicine III, Medical University of Vienna, Vienna, Austria

Correspondence should be addressed to F W Kiefer Email

florian.kiefer@meduniwien. ac.at

\begin{abstract}
Promotion of brown adipose tissue (BAT) activity or browning of white adipose tissue has shown great potential as anti-obesity strategy in numerous preclinical models. The discovery of active BAT in humans and the recent advances in the understanding of human BAT biology and function have significantly propelled this field of research. Pharmacological stimulation of energy expenditure to counteract obesity has always been an intriguing therapeutic concept; with the identification of the specific molecular pathways of brown fat function, this idea has now become as realistic as ever. Two distinct strategies are currently being pursued; one is the activation of bone fide BAT, the other is the induction of BAT-like cells or beige adipocytes within white fat depots, a process called browning. Recent evidence suggests that both phenomena can occur in humans. Cold-induced promotion of BAT activity is strongly associated with enhanced thermogenesis and energy expenditure in humans and has beneficial effects on fat mass and glucose metabolism. Despite these encouraging results, a number of issues deserve additional attention including the distinct characteristics of human vs rodent BAT, the heterogeneity of human BAT depots or the identification of the adipocyte precursors that can give rise to thermogenic cells in human adipose tissue. In addition, many pharmaceutical compounds are being tested for their ability to promote a thermogenic program in human adipocytes. This review summarizes the current knowledge about the various cellular and molecular aspects of human BAT as well as the relevance for energy metabolism including its therapeutic potential for obesity.
\end{abstract}

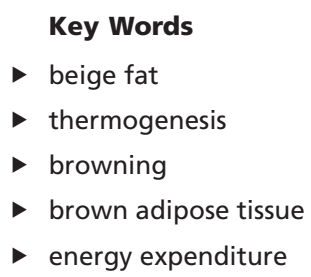

Endocrine Connections (2017) 6, R70-R79

\section{Introduction}

There is now a large body of evidence - at least in rodents - that the actions of brown adipose tissue (BAT) or the browning of white adipose tissue (WAT) can protect against obesity and related complications $(1,2,3)$. The molecular mechanisms that are responsible for the energy-dissipating qualities of brown fat have been studied in detail $(4,5)$. Uncoupling protein-1 (UCP-1) has been identified as the key factor controlling the thermogenic capacity of brown adipocytes (6). UCP-1 disrupts the electrochemical gradient across the mitochondrial membrane by allowing protons to reenter the mitochondrial matrix.
Consequently, mitochondrial fatty acid oxidation is increased and chemical energy is wasted through heat production (thermogenesis) $(4,7)$. This process has long been believed to occur exclusively in brown adipocytes; however, in recent years, a large number of studies have reported about the emergence of UCP-1-positive cells in WAT with very similar properties as BAT cells $(3,8,9)$. These cells have been termed 'beige' or 'brite' because of their intermediate function between brown and white adipocytes. A hallmark of beige adipocytes is their potential to take on a thermogenic phenotype in response
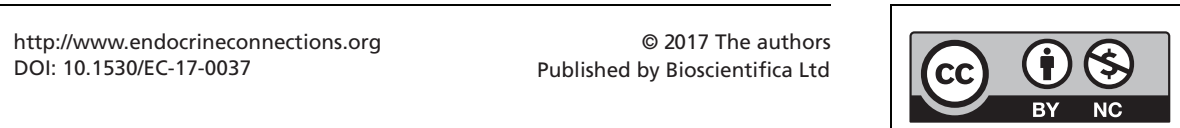

This work is licensed under a Creative Commons Attribution-NonCommercial 4.0 International License. 
to various stimuli such as cold, chemical compounds or genetic factors. Under basal conditions, beige cells express very similar molecular markers as classic white adipocytes (with low UCP-1 levels); however, when appropriately stimulated, they acquire a thermogenic signature with high UCP-1 expression and increased energy consumption similar to bone fide brown adipocytes $(2,3$, $10,11,12,13)$. Despite some mutual features, brown and beige adipocytes also have very distinct characteristics. For instance, they differ in their anatomical location; whereas beige cells emerge within WAT, particularly in the subcutaneous depots, classic brown adipocytes reside within bone fide BAT typically located in the interscapular region in rodents and human infants $(3,13,14)$. Another difference between brown and beige adipocytes pertains to their developmental origin. Classical brown adipocytes originate from precursor cells in the embryonic mesoderm that express the transcription factor myogenic factor 5 (MYF5) and can give rise to either brown adipocytes or myocytes. The transcriptional co-regulator PR domain containing 16 (PRDM16) has been shown to control the switch between myogenic vs adipogenic differentiation in the MYF5-positive precursors $(15,16)$. In contrast, beige adipocytes are believed to come from a MYF5-negative lineage. However, the exact origin of beige adipocytes still remains a matter of great debate given that recent lineage tracing studies in rodents provide evidence for two fundamentally different concepts (3). One is the so-called precursor model because it implies that beige adipocytes are derived from a distinct progenitor cell population by de novo differentiation in response to distinct stimuli such as prolonged cold exposure or certain genetic modifications. The other concept proposes that mature white adipocytes can transdifferentiate into beige adipocytes when appropriately challenged and has therefore been termed transdifferentiation or more accurately interconversion model $(8,17,18)$. Given the context in which these fate-mapping studies have been performed, it is possible that both developmental models are correct and that additional factors such as the environment (e.g. ambient temperature), the genetic background or fat depot specific differences may influence the decision how beige cells finally develop. Regardless of the precise developmental origin, the induction of thermogenically active beige adipocytes in WAT has proven to be effective in preventing or reducing obesity and diabetes in numerous preclinical models.

Current research is directed at discovering the various molecular cues that induce such a browning program

http://www.endocrineconnections.org DOI: 10.1530/EC-17-0037

(c) 2017 The authors Published by Bioscientifica Ltd in WAT. Besides chronic cold exposure, a number of transcription factors and co-regulators have been identified to control the browning process. Among those are peroxisome proliferator-activated receptor $\gamma$ coactivator $1 \alpha$ (PGC-1 $\alpha)$, PRDM16, bone morphogenic proteins and many more (1). In addition, circulating factors such as thyroid hormones, bile acids, natriuretic peptides, retinoids, fibroblast growth factor 21 (FGF-21) and various cytokines can regulate a thermogenic program in WAT $(14,19,20,21,22,23)$. Notably, physical exercise has also been demonstrated to promote WAT browning in mice through a muscle-derived hormone named irisin (24). However, it is still a matter of investigation which of these pathways are conserved in humans and to what extent they contribute to thermogenesis and energy dissipation.

\section{Detection of active human BAT}

Despite previous observations in cancer patients undergoing positron emission tomography combined with X-ray computed tomography (PET/CT) showing significant uptake of radioactively labeled glucose ${ }^{18} \mathrm{~F}$-fluorodeoxyglucose (FDG) in various cervical and thoracic fat depots, the metabolic relevance of this tissue has long been neglected. In fact, the FDG-positive fat depots have been viewed as impediment to diagnostic imaging because the signal could obscure tumor visualization or introduce false positive results $(25,26)$. Therefore, beta blockers have occasionally been used to repress the unwanted FDG uptake (27). However, the interest in these FDG-positive fat depots has risen significantly since 2009 when three prospective PET/CT studies coupled with tissue biopsies in human adults showed that these BAT depots contained UCP-1-expressing cells and could be activated by cold exposure $(28,29,30)$. Notably, very early studies including one in Finnish outdoor workers had already indicated that the occurrence of BAT may be influenced by ambient temperatures (31). In line with these early observations are newer reports of seasonal variations in BAT activity showing negative correlations with average outdoor temperatures $(32,33)$.

In humans, BAT depots are typically located in the deep cervical, supraclavicular, parasternal and sometimes perirenal regions $(28,29,30,34$ and Fig. 1). In some rare cases of pheochromocytoma, significant FDG uptake has also been detected in visceral adipose tissue reflecting a browning of this WAT compartment due to the prolonged stimulation with endogenous catecholamines $(35,36)$. 


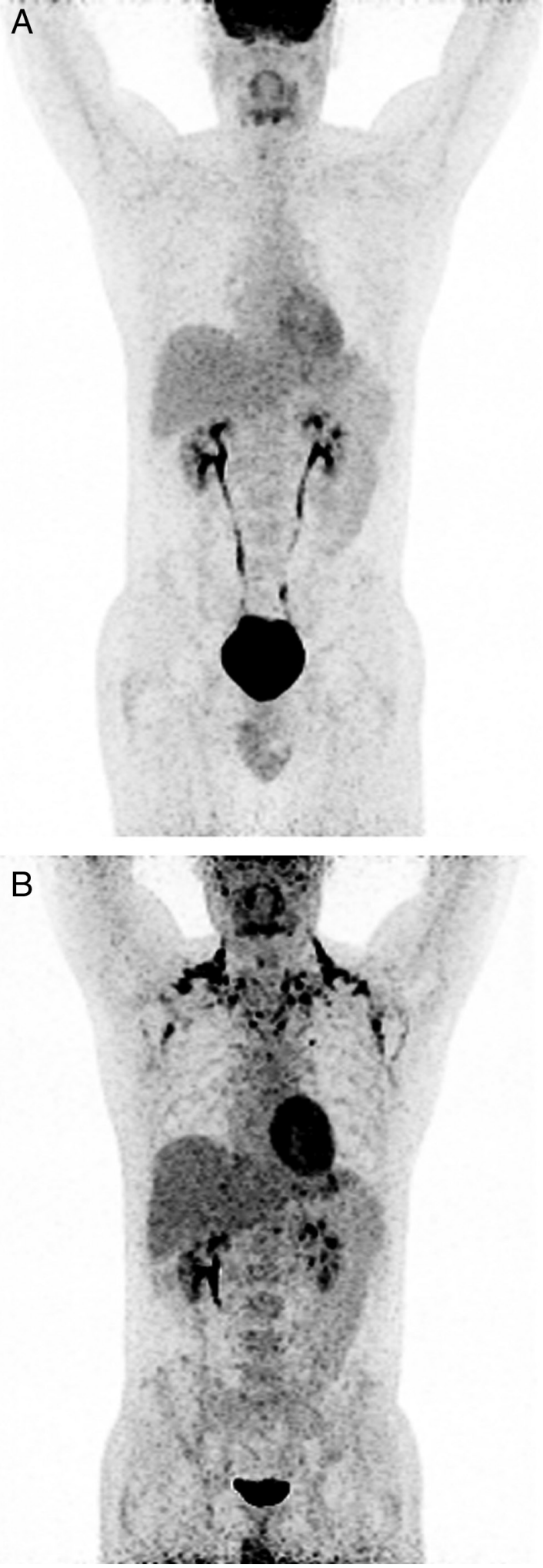

Figure 1

Representative ${ }^{18} \mathrm{FDG}-\mathrm{PET} / \mathrm{CT}$ scans before (A) and after (B) short-term cold exposure. FDG-positive BAT depots are visible at the typical cervical, clavicular and paravertebral regions.

http://www.endocrineconnections.org DOI: 10.1530/EC-17-0037

(C) 2017 The author Published by Bioscientifica Ltd
However, after surgical removal of the tumor, FDG uptake was no longer present in the visceral fat suggesting reversal of the browning process (35).

Despite some limitations, FDG-PET/CT evolved as the gold standard for imaging human BAT, although a number of alternative approaches are currently being investigated. Particularly non-radioactive imaging techniques such as magnetic resonance imaging (MRI) have recently been pursued given that repeated PET/CT studies within the same individuals are limited due to the cumulative radiation exposure. Chemical-shift-encoded water-fat MRI allows to estimate the time-resolved fat fraction, which has been helpful to distinguish between WAT and BAT and also between active and inactive BAT $(37,38,39)$. Other research is directed at testing alternative radiotracers beyond FDG $(40,41)$. Given that BAT is primarily utilizing fatty acids as fuel substrate, various lipid tracers such as ${ }^{11} \mathrm{C}$-acetate and ${ }^{18} \mathrm{~F}$-fluoro-thiaheptadecanoic acid have been studied (42). However, FDG-PET/CT continues to be the most important platform for the detection and quantification of human BAT. In order to standardize the protocols for FDG-PET/CT imaging of human BAT and to ease comparisons between different studies, an expert panel assembled by the National Institute of Health (NIH) has established the first guidelines in 2014 (43). The 'Brown Adipose Reporting Criteria in Imaging Studies' (BARCIST) provide recommendations for experimental parameters and minimum requirements for acquisition, analysis and reporting of FDG-PET/CT BAT data in humans.

\section{Beige or brown: does it really matter?}

Ever since the discovery of cold-induced BAT in humans, researchers have tried to better understand the molecular characteristics of this adipose depot. Therefore, biopsy studies of FDG-positive neck fat depots have been performed to establish the genetic signature of human BAT. By comparing the results from human fat biopsies with those from mouse fat depots, researchers have tried to address the question whether human BAT resembles the molecular and functional aspects of bone fide brown or beige fat. Currently, there is evidence for both, which can in part be explained by the large heterogeneity of the human BAT samples studied. Depending upon the exact anatomical location, human BAT has been suggested to display either a classical brown or a beige signature or both $(44,45,46,47)$. Another important limitation besides the heterogeneous composition of human brown

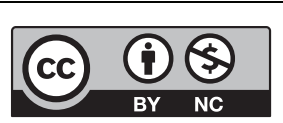

This work is licensed under a Creative Commons Attribution-NonCommercial 4.0 International License. 
fat depots is the fact that the marker genes that have been used for genetic characterization of human BAT have previously been identified in mouse tissues (10, $45,48)$. These gene sets may not fully reproduce the molecular landscape of human BAT, which makes it more challenging to unequivocally distinguish between beige and brown fat in humans. In this context, it is noteworthy that thermoneutral conditions occur at different ambient temperatures in mice and humans that is mice require slightly higher temperatures for thermoneutrality. Even though it is still a matter of debate which is the optimal housing temperature for mice to best mimic human thermal conditions, this needs to be considered when comparing molecular and functional aspects of human and murine brown/beige adipocytes $(49,50,51)$. Regardless of those experimental caveats, human BAT is a metabolically highly active tissue with a respiratory capacity up to 50-fold greater than WAT and comparable to rodent BAT when normalized to the mitochondrial content (52).

Another important issue that has recently drawn a lot of interest is the capacity of human WAT to acquire BAT-like features. Turning the large amounts of white fat, as seen in obese subjects, into energy-dissipating beige fat represents an intriguing concept with great potential for therapeutic applications. Reports from pheochromocytoma patients with FDG-positive intra-abdominal WAT depots containing adipocytes with high UCP-1 expression suggest that browning of visceral WAT can occur in response to catecholamine excess $(35,36,53,54)$. A more recent study in intensive care patients found that subcutaneous fat can also undergo significant browning under extreme conditions. Severe burn injuries led to the emergence of UCP-1-positive beige cells within the subcutaneous fat with a maximum several weeks after the trauma. This observation was linked to the severe adrenergic stress and the prolonged elevation of norepinephrine levels seen after such burn injuries (55). Likewise, a case study in a patient with papillary thyroid carcinoma found that TSHsuppressing treatment with levothyroxine (T4) induced BAT activity and browning of subcutaneous adipose tissue (56). The relevance of thyroid hormones for adipose browning in humans is also supported by findings that circulating free $\mathrm{T} 4$ concentrations significantly correlated with gene expression of classic brown fat markers in the subcutaneous WAT of 163 middle-aged obese men and women (57). Whether browning of WAT can also be induced under controlled pharmacological conditions and whether that results in increased energy wasting and body weight loss in humans is yet to be shown.

\section{Function of human BAT: relevance for energy metabolism}

Soon after the detection of cold-induced BAT in human adults in 2009, numerous follow-up studies confirmed that activated BAT contributed to non-shivering thermogenesis and oxidative metabolism in humans. Energy dissipation is significantly increased with BAT activation and was reported to account for up to $15 \%$ of resting energy expenditure in men (58). Chronic cold exposure ( $2 \mathrm{~h}$ daily for six weeks) resulted not only in enhanced BAT activity and cold-induced thermogenesis but also in a significant loss of body fat mass. The reduction in fat mass was greater in subjects with higher BAT activity and correlated with the degree of cold-induced thermogenesis (59). Both, glucose and fatty acid uptake contribute to increased BAT oxidative metabolism in humans $(42,60,61,62)$. Using hyperinsulinemic-euglycemic clamp studies, BAT activation was shown to improve whole-body glucose disposal and insulin sensitivity confirming its relevance for total energy metabolism $(58,61)$. However, rapidly elevated BAT radiodensity after short-term cold exposure led to the hypothesis that acute BAT thermogenesis is fueled predominantly by fatty acids hydrolyzed from intracellular triglycerides. This hypothesis has been tested in a recent study using ${ }^{11} \mathrm{C}$-acetate and ${ }^{18} \mathrm{~F}$-FDG-PET/CT in combination with acute cold exposure and oral nicotinic acid, an inhibitor of intracellular triglyceride lipolysis (63). Not only did nicotinic acid administration suppress cold-induced BAT oxidative metabolism and glucose uptake in healthy men, but it also led to an increase in skeletal muscle shivering intensity. These results suggest that intracellular triglyceride lipolysis is likely essential for BAT thermogenesis and provide experimental evidence for a reciprocal role of non-shivering thermogenesis in BAT and shivering thermogenesis in skeletal muscle. In recent years, the importance of BAT as a major site for lipoprotein metabolism has been increasingly appreciated thanks largely to mouse models that demonstrated that coldactivated BAT can effectively clear plasma triglycerides predominantly through the actions of lipoprotein lipase and CD36 $(64,65,66)$. Moreover, BAT activation mitigates hypercholesterinemia and atherosclerotic plaque formation $(66,67)$, suggesting a potential cardioprotective role, possibly independent of increased energy expenditure and weight loss. Whether this concept holds true for cardiovascular disease in humans is yet to be shown. Besides cardiovascular protection, another important question from a therapeutic standpoint is, whether active BAT can be recruited in obese and/or

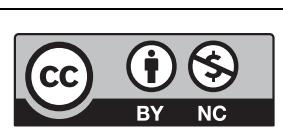

This work is licensed under a Creative Commons Attribution-NonCommercial 4.0 International License. 
type 2 diabetic subjects in order to promote weight loss and/or improve glucose metabolism. Although an inverse relationship between BAT activity and body mass or BMI has been repeatedly reported $(68,69)$, short-term cold acclimation (up to $6 \mathrm{~h}$ per day over 10 days) was capable to recruit active BAT in obese subjects as determined by FDG uptake in PET/CT scans (70). Interestingly, the recruitment of BAT during cold acclimation was not associated with any elevation in energy expenditure, which may be a consequence of the modest increase in BAT activity observed in this study. However, when comparing BATpositive with BAT-negative subjects, there is a plethora of evidence for higher cold-induced thermogenesis, enhanced energy expenditure and improved whole-body glucose homeostasis in those with active BAT irrespective of the body mass $(58,59,68,69)$. A hyperinsulinemiceuglycemic clamp study in overweight men with type 2 diabetes found that 10-day cold acclimation significantly enhanced BAT activity and improved whole-body insulin sensitivity by $43 \%$, which was mainly driven by increased insulin-stimulated glucose disposal (61). Interestingly, enhanced skeletal muscle glucose uptake due to elevated GLUT4 translocation seemed to account for majority of the glycemic effects seen in this study, raising the possibility that activated BAT may release endocrine factors that engage other metabolic tissues such as skeletal muscle. Recent evidence suggests that BAT is indeed a source of hormone production and that these BAT-derived factors may play a role in systemic energy metabolism.

\section{BAT as a secretory organ}

In addition to its function as a thermogenic organ, BAT has recently been identified as a tissue with high secretory capacity. Accumulating evidence from preclinical studies suggests that molecules released from BAT differ significantly from those released from WAT. The so-called BAT adipokines or BATokines can act in an autocrine, paracrine or endocrine fashion (71). Most of the autocrine and paracrine molecules such as nerve growth factor, fibroblastic growth factor 2 and vascular endothelial growth factor-A promote BAT growth, vascularization, innervation and blood flow, processes that are important for BAT recruitment during thermogenic stimulation (71). Strong evidence for BAT as an endocrine organ came from BAT transplantation studies in mice and rats. The transplantation of BAT into diabetic or diet-induced obese mice significantly improved glycemic conditions, WAT inflammation and systemic adipokine profiles (72, 73, 74). Secretion of insulin-like growth factor 1 has been proposed as one endocrine mechanism for the antidiabetic actions of transplanted BAT (72). Morphological and molecular studies from transplanted BAT revealed larger adipocyte size and decreased thermogenic gene expression in comparison to endogenous BAT (73). These findings suggested that the beneficial effects of BAT transplantation may not primarily be driven by the intrinsic thermogenic activity but by endocrine factors released from the transplant. Additional support for this concept came from a study showing that the favorable metabolic effects of BAT transplantation were lost when interleukin-6 (IL-6)deficient mice were used as donors, suggesting IL- 6 as another endocrine mediator of transplanted BAT (74). IL-6 has previously been identified to be secreted form activated brown adipocytes (75). The role of IL-6 as a classic pro-inflammatory cytokine has to be reconsidered in light of recent data that IL- 6 signaling can promote insulin sensitivity in skeletal muscle and adipose tissue of mice $(76,77)$. The importance for BAT as secretory organ has also been highlighted by a recent report identifying BAT as a source for circulating exosomal miRNAs, which function as negative regulators of translation. Transplantation of BAT into mice lacking the miRNA-processing enzyme Dicer restored the levels of numerous circulating miRNAs that are associated with an improvement in glucose tolerance (78). Interestingly, serum concentrations of the exosomal miRNA miR-92 have been reported to correlate with BAT glucose uptake in human PET/CT studies, suggesting miRNAs as potential new biomarkers for BAT activity (79). In this context, a new class of lipids has been identified, that is released from tissues and acts locally or systemically on energy turnover, glucose metabolism and inflammatory pathways $(80,81)$. One of these so-called lipokines is the BAT-derived 12,13-dihydroxy9Z-octadecenoic acid (12,13-diHOME), which is increased in response to cold exposure and promotes BAT activation in a feedforward mechanism (82). In search for new BAT biomarkers, targeted metabolomics recently showed that the lipid lysophosphatidylcholine-acyl C16:0 is strongly associated with BAT activity in humans as determined by PET/CT scans (83). These findings highlight the promising developments in the identification of novel non-invasive markers for the prediction of metabolically active BAT in humans.

Another circulating molecule that has lately received a lot of attention is fibroblast growth factor 21 (FGF21), which is mainly secreted by the liver but

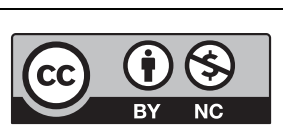


also by activated brown adipocytes (84). FGF21 acts in concert with the cofactor $\beta$-Klotho, which is required for the interaction with FGF receptors (85). FGF21 regulates energy metabolism through multiple pathways including enhanced browning of WAT and accelerated lipoprotein catabolism $(23,65)$. In addition, FGF21 alters food preferences through hypothalamic signals that is decreased desire for sweets and consequently reduces carbohydrate intake in mice $(86,87)$. As a result, FGF21 actions counteract diet-induced obesity, hyperglycemia and hyperlipidemia in various animal models. Notably, FGF21 is also expressed in human BAT and cold exposure increases circulating concentrations of FGF21 in humans, possibly as a reflection of enhanced BAT activation (88). In isolated human brown adipocytes, FGF21 and the muscle-derived hormone irisin have additive effects on norepinephrine-stimulated thermogenesis (89). Clinical trials are currently underway to test the efficacy and safety of FGF21 analogs in human metabolic disease. Initial data on long-acting FGF21 analogs in overweight/obese type 2 diabetic subjects demonstrated a significant decrease in body weight together with improved plasma lipid profiles and elevation of circulating adiponectin levels. However, blood glucose levels were not significantly reduced, whereas markers of bone turnover increased in a dose-dependent manner, which tempered the previous enthusiasm of FGF21-based treatment for metabolic disease $(90,91)$.

\section{Pharmacological activation of human BAT and outlook}

Given the persuasive evidence from various preclinical and clinical studies that the promotion of BAT function has beneficial effects on total energy metabolism, pharmacologic activation of human BAT holds great promise as a therapeutic concept in metabolic disease. Among pharmacological substances, $\beta 3$-agonists are well known to induce UCP-1 expression and thermogenesis in vivo in rodents and in vitro in isolated brown adipocytes $(4,92,93,94)$. Although initial attempts with $\beta 3$-agonists have failed to increase BAT activity in humans (95), a recent study showed that mirabegron, a $\beta 3$-agonist approved for the treatment of overactive bladder, activates BAT and elevates energy expenditure in humans similar to cold exposure (96). However, the potential cardiovascular side effects of $\beta 3$-agonists may limit their broad use in humans. Non-pungent capsaicin analogs (capsinoids) may represent an alternative therapeutic approach. Capsaicin enhances thermogenic gene expression and browning of WAT in mice through stimulation of transient receptor potential channels (97). Moreover, a six-week treatment with oral capsinoids increased cold-induced thermogenesis and energy expenditure in subjects with previously low or undetectable BAT activity. However, the effects were not sufficient to induce a loss of body weight or fat mass (59). In contrast, treatment with the antidiabetic agent liraglutide, which acts as an agonist at the glucagon-like peptide-1 (GLP-1) receptor results in significant weight loss in obese subjects (98). GLP-1-mediated weight loss is mainly driven by delayed gastric emptying and appetite suppression (99). However, a recent study found that energy expenditure is also increased in liraglutide-treated obese patients with type 2 diabetes (100). Interestingly, intracerebral liraglutide administration in mice stimulated BAT thermogenesis and browning of WAT through hypothalamic adenosine monophosphate-activated protein kinase action (100). Whether GLP-1 agonist mediated weight loss seen in humans also involves altered BAT activity is still a matter of investigation. The bile acid chenodeoxycholic acid (CDCA) on the other hand has already been demonstrated to increase BAT activity in mice and humans $(101,102)$. Ingestion of $15 \mathrm{mg} / \mathrm{kg}$ CDCA for two subsequent days significantly stimulated BAT FDG uptake in young healthy women and CDCA treatment in isolated human brown adipocytes enhanced mitochondrial respiration (102). In addition to the activation of the nuclear farnesoid $X$ receptor, bile acids signal through the $G$ protein-coupled receptor TGR5, which leads to thermogenic activation of brown adipocytes through the actions of intracellular thyroid hormones (103). Other intriguing drug targets are bone morphogenic proteins (BMPs), in particular BMP7 and BMP8b, which are important for brown adipocyte development, the thermogenic response of BAT and the browning of WAT $(104,105,106)$. Central actions of BMP8b also include increased sympathetic outflow to BAT, which resulted in weight loss in mice (105).

Although these early findings are very promising, more studies will be needed to assess the potency of these factors to recruit brown or beige adipocytes in humans. Current research is also directed at identifying the cell population in human fat depots that can undergo efficient thermogenic transformation in response to pharmacological stimuli. Even if new therapeutic interventions will achieve successful expansion and activation of BAT in humans, it remains to be seen whether http://www.endocrineconnections.org DOI: 10.1530/EC-17-0037
() 2017 The authors Published by Bioscientifica Ltd
This work is licensed under a Creative Commons Attribution-NonCommercial 4.0 International License. 
persistent weight loss and improved glucose metabolism will be the consequence. Given the tight control of energy balance under physiologic conditions, it is possible that increased appetite and food intake will compensate for the energy wasting induced by BAT activation. Hence, a combined intervention targeting both, adipose tissue thermogenesis and central appetite regulation, may represent the most effective therapeutic approach in the fight against obesity and related metabolic complications.

\section{Declaration of interest}

The author declares that there is no conflict of interest that could be perceived as prejudicing the impartiality of this review.

\section{Funding}

This work was supported by the Vienna Science and Technology Fund (WWTF) project LS12-059 and the Austrian Science Fund (FWF) project P27391-B26 (both to F W K).

\section{References}

1 Harms M \& Seale P. Brown and beige fat: development, function and therapeutic potential. Nature Medicine 201319 1252-1263. (doi:10.1038/nm.3361)

2 Bartelt A \& Heeren J. Adipose tissue browning and metabolic health. Nature Reviews Endocrinology 201410 24-36. (doi:10.1038/ nrendo.2013.204)

3 Kiefer FW. Browning and thermogenic programing of adipose tissue. Best Practice and Research Clinical Endocrinology and Metabolism 201630 479-485. (doi:10.1016/j.beem.2016.09.003)

4 Cannon B \& Nedergaard J. Brown adipose tissue: function and physiological significance. Physiological Reviews 200484 277-359. (doi:10.1152/physrev.00015.2003)

5 Rosen ED \& Spiegelman BM. What we talk about when we talk about fat. Cell 2014156 20-44. (doi:10.1016/j.cell.2013.12.012)

6 Klingenberg M. Uncoupling protein - a useful energy dissipator. Journal of Bioenergetics and Biomembranes 199931 419-430. (doi:10.1023/A:1005440221914)

7 Fenzl A \& Kiefer FW. Brown adipose tissue and thermogenesis. Hormone Molecular Biology and Clinical Investigation 201419 25-37. (doi:10.1515/hmbci-2014-0022)

8 Barbatelli G, Murano I, Madsen L, Hao Q, Jimenez M, Kristiansen K, Giacobino JP, De Matteis R \& Cinti S. The emergence of cold-induced brown adipocytes in mouse white fat depots is determined predominantly by white to brown adipocyte transdifferentiation. American Journal of Physiology: Endocrinology and Metabolism 2010298 E1244-E1253. (doi:10.1152/ ajpendo.00600.2009)

9 Cao L, Choi EY, Liu X, Martin A, Wang C, Xu X \& During MJ. White to brown fat phenotypic switch induced by genetic and environmental activation of a hypothalamic-adipocyte axis. Cell Metabolism 201114 324-338. (doi:10.1016/j.cmet.2011.06.020)

10 Wu J, Bostrom P, Sparks LM, Ye L, Choi JH, Giang AH, Khandekar M, Virtanen KA, Nuutila P, Schaart G, et al. Beige adipocytes are a distinct type of thermogenic fat cell in mouse and human. Cell 2012150 366-376. (doi:10.1016/j. cell.2012.05.016)

11 Ishibashi J \& Seale P. Medicine. Beige can be slimming. Science 2010328 1113-1114. (doi:10.1126/science.1190816)
12 Kim SH \& Plutzky J. Brown fat and browning for the treatment of obesity and related metabolic disorders. Diabetes and Metabolism Journal 201640 12-21. (doi:10.4093/dmj.2016.40.1.12)

13 Sanchez-Gurmaches J, Hung CM \& Guertin DA. Emerging complexities in adipocyte origins and identity. Trends in Cell Biology 201626 313-326. (doi:10.1016/j.tcb.2016.01.004)

14 Kajimura S, Spiegelman BM \& Seale P. Brown and beige fat: physiological roles beyond heat generation. Cell Metabolism 2015 22 546-559. (doi:10.1016/j.cmet.2015.09.007)

15 Seale P, Bjork B, Yang W, Kajimura S, Chin S, Kuang S, Scime A, Devarakonda S, Conroe HM, Erdjument-Bromage H, et al. PRDM16 controls a brown fat/skeletal muscle switch. Nature 2008 454 961-967. (doi:10.1038/nature07182)

16 Seale P, Kajimura S \& Spiegelman BM. Transcriptional control of brown adipocyte development and physiological function - of mice and men. Genes and Development 200923 788-797. (doi:10.1101/gad.1779209)

17 Lee YH, Petkova AP, Mottillo EP \& Granneman JG. In vivo identification of bipotential adipocyte progenitors recruited by beta3-adrenoceptor activation and high-fat feeding. Cell Metabolism 201215 480-491. (doi:10.1016/j.cmet.2012.03.009)

18 Wang QA, Tao C, Gupta RK \& Scherer PE. Tracking adipogenesis during white adipose tissue development, expansion and regeneration. Nature Medicine 201319 1338-1344. (doi:10.1038/ nm.3324)

19 Weiner J, Hankir M, Heiker JT, Fenske W \& Krause K. Thyroid hormones and browning of adipose tissue. Molecular and Cellular Endocrinology 2017 [in press]. (doi:10.1016/j.mce.2017.01.011)

20 Fang S, Suh JM, Reilly SM, Yu E, Osborn O, Lackey D, Yoshihara E, Perino A, Jacinto S, Lukasheva Y, et al. Intestinal FXR agonism promotes adipose tissue browning and reduces obesity and insulin resistance. Nature Medicine 201521 159-165. (doi:10.1038/nm.3760)

21 Bordicchia M, Liu D, Amri EZ, Ailhaud G, Dessi-Fulgheri P, Zhang C, Takahashi N, Sarzani R \& Collins S. Cardiac natriuretic peptides act via p38 MAPK to induce the brown fat thermogenic program in mouse and human adipocytes. Journal of Clinical Investigation 2012122 1022-1036. (doi:10.1172/JCI59701)

22 Kiefer FW, Vernochet C, O'Brien P, Spoerl S, Brown JD, Nallamshetty S, Zeyda M, Stulnig TM, Cohen DE, Kahn CR, et al. Retinaldehyde dehydrogenase 1 regulates a thermogenic program in white adipose tissue. Nature Medicine 201218 918-925. (doi:10.1038/nm.2757)

23 Fisher FM, Kleiner S, Douris N, Fox EC, Mepani RJ, Verdeguer F, Wu J, Kharitonenkov A, Flier JS, Maratos-Flier E, et al. FGF21 regulates PGC-1alpha and browning of white adipose tissues in adaptive thermogenesis. Genes and Development 201226 271-281. (doi:10.1101/gad.177857.111)

24 Bostrom P, Wu J, Jedrychowski MP, Korde A, Ye L, Lo JC, Rasbach KA, Bostrom EA, Choi JH, Long JZ, et al. A PGC1-alpha-dependent myokine that drives brown-fat-like development of white fat and thermogenesis. Nature 2012481 463-468. (doi:10.1038/ nature10777)

25 Yeung HW, Grewal RK, Gonen M, Schoder H \& Larson SM. Patterns of (18)F-FDG uptake in adipose tissue and muscle: a potential source of false-positives for PET. Journal of Nuclear Medicine 200344 1789-1796.

26 Cohade C, Osman M, Pannu HK \& Wahl RL. Uptake in supraclavicular area fat ('USA-Fat'): description on 18F-FDG PET/ CT. Journal of Nuclear Medicine 200344 170-176.

27 Parysow O, Mollerach AM, Jager V, Racioppi S, San Roman J \& Gerbaudo VH. Low-dose oral propranolol could reduce brown adipose tissue F-18 FDG uptake in patients undergoing PET scans. Clinical Nuclear Medicine 200732 351-357. (doi:10.1097/01. rlu.0000259570.69163.04)
This work is licensed under a Creative Commons Attribution-NonCommercial 4.0 International License. 
28 Cypess AM, Lehman S, Williams G, Tal I, Rodman D, Goldfine $\mathrm{AB}$, Kuo FC, Palmer EL, Tseng YH, Doria A, et al. Identification and importance of brown adipose tissue in adult humans. New England Journal of Medicine 2009360 1509-1517. (doi:10.1056/ NEJMoa0810780)

29 Virtanen KA, Lidell ME, Orava J, Heglind M, Westergren R, Niemi T, Taittonen M, Laine J, Savisto NJ, Enerback S, et al. Functional brown adipose tissue in healthy adults. New England Journal of Medicine 2009360 1518-1525. (doi:10.1056/NEJMoa0808949)

30 Saito M, Okamatsu-Ogura Y, Matsushita M, Watanabe K, Yoneshiro T, Nio-Kobayashi J, Iwanaga T, Miyagawa M, Kameya T, Nakada K, et al. High incidence of metabolically active brown adipose tissue in healthy adult humans: effects of cold exposure and adiposity. Diabetes 200958 1526-1531. (doi:10.2337/db090530)

31 Huttunen P, Hirvonen J \& Kinnula V. The occurrence of brown adipose tissue in outdoor workers. European Journal of Applied Physiology and Occupational Physiology 198146 339-345. (doi:10.1007/BF00422121)

32 Cohade C, Mourtzikos KA \& Wahl RL. 'USA-Fat': prevalence is related to ambient outdoor temperature-evaluation with 18F-FDG PET/CT. Journal of Nuclear Medicine 200344 1267-1270.

33 Au-Yong IT, Thorn N, Ganatra R, Perkins AC \& Symonds ME. Brown adipose tissue and seasonal variation in humans. Diabetes 200958 2583-2587. (doi:10.2337/db09-0833)

34 Nagano G, Ohno H, Oki K, Kobuke K, Shiwa T, Yoneda M \& Kohno N. Activation of classical brown adipocytes in the adult human perirenal depot is highly correlated with PRDM16-EHMT1 complex expression. PLOS ONE 201510 e0122584. (doi:10.1371/ journal.pone.0122584)

35 Ramacciotti C, Schneegans O, Lang H, Lindner V, Claria M, Moreau F, Chenard MP, Pinget M \& Kessler L. Diffuse uptake of brown fat on computed-tomography coupled positron emission tomoscintigraphy (PET-CT) for the exploration of extra-adrenal pheochromocytoma. Annales d'Endocrinologie 200667 14-19.

36 Wang Q, Zhang M, Ning G, Gu W, Su T, Xu M, Li B \& Wang W. Brown adipose tissue in humans is activated by elevated plasma catecholamines levels and is inversely related to central obesity. PLOS ONE 20116 e21006. (doi:10.1371/journal. pone.0021006)

37 Lundstrom E, Strand R, Johansson L, Bergsten P, Ahlstrom H \& Kullberg J. Magnetic resonance imaging cooling-reheating protocol indicates decreased fat fraction via lipid consumption in suspected brown adipose tissue. PLoS ONE 201510 e0126705. (doi:10.1371/journal.pone.0126705)

38 Gifford A, Towse TF, Walker RC, Avison MJ \& Welch EB. Characterizing active and inactive brown adipose tissue in adult humans using PET-CT and MR imaging. American Journal of Physiology: Endocrinology and Metabolism 2016311 E95-E104. (doi:10.1152/ajpendo.00482.2015)

39 Stahl V, Maier F, Freitag MT, Floca RO, Berger MC, Umathum R, Berriel Diaz M, Herzig S, Weber MA, Dimitrakopoulou-Strauss A, et al. In vivo assessment of cold stimulation effects on the fat fraction of brown adipose tissue using DIXON MRI. Journal of Magnetic Resonance Imaging 201745 369-380. (doi:10.1002/ jmri.25364)

40 Baba S, Engles JM, Huso DL, Ishimori T \& Wahl RL. Comparison of uptake of multiple clinical radiotracers into brown adipose tissue under cold-stimulated and nonstimulated conditions. Journal of Nuclear Medicine 200748 1715-1723. (doi:10.2967/ jnumed.107.041715)

41 Madar I, Isoda T, Finley P, Angle J \& Wahl R. 18F-fluorobenzyl triphenyl phosphonium: a noninvasive sensor of brown adipose tissue thermogenesis. Journal of Nuclear Medicine 201152 808-814. (doi:10.2967/jnumed.110.084657)
42 Ouellet V, Labbe SM, Blondin DP, Phoenix S, Guerin B, Haman F, Turcotte EE, Richard D \& Carpentier AC. Brown adipose tissue oxidative metabolism contributes to energy expenditure during acute cold exposure in humans. Journal of Clinical Investigation 2012122 545-552. (doi:10.1172/JCI60433)

43 Chen KY, Cypess AM, Laughlin MR, Haft CR, Hu HH, Bredella MA, Enerback S, Kinahan PE, Lichtenbelt W, Lin FI, et al. Brown Adipose Reporting Criteria in Imaging STudies (BARCIST 1.0): recommendations for standardized FDG-PET/CT experiments in humans. Cell Metabolism 201624 210-222. (doi:10.1016/j. cmet.2016.07.014)

44 Lee P, Swarbrick MM, Zhao JT \& Ho KK. Inducible brown adipogenesis of supraclavicular fat in adult humans. Endocrinology 2011152 3597-3602. (doi:10.1210/en.2011-1349)

45 Cypess AM, White AP, Vernochet C, Schulz TJ, Xue R, Sass CA, Huang TL, Roberts-Toler C, Weiner LS, Sze C, et al. Anatomical localization, gene expression profiling and functional characterization of adult human neck brown fat. Nature Medicine 201319 635-639. (doi:10.1038/nm.3112)

46 Jespersen NZ, Larsen TJ, Peijs L, Daugaard S, Homoe P, Loft A, de Jong J, Mathur N, Cannon B, Nedergaard J, et al. A classical brown adipose tissue mRNA signature partly overlaps with brite in the supraclavicular region of adult humans. Cell Metabolism 201317 798-805. (doi:10.1016/j.cmet.2013.04.011)

47 Shinoda K, Luijten IH, Hasegawa Y, Hong H, Sonne SB, Kim M, Xue R, Chondronikola M, Cypess AM, Tseng YH, et al. Genetic and functional characterization of clonally derived adult human brown adipocytes. Nature Medicine 201521 389-394. (doi:10.1038/nm.3819)

48 Svensson PA, Jernas M, Sjoholm K, Hoffmann JM, Nilsson BE, Hansson M \& Carlsson LM. Gene expression in human brown adipose tissue. International Journal of Molecular Medicine 201127 227-232.

49 Lodhi IJ \& Semenkovich CF. Why we should put clothes on mice. Cell Metabolism 20099 111-112. (doi:10.1016/j. cmet.2009.01.004)

50 Cannon B \& Nedergaard J. Nonshivering thermogenesis and its adequate measurement in metabolic studies. Journal of Experimental Biology 2011214 242-253. (doi:10.1242/jeb.050989)

51 Speakman JR \& Keijer J. Not so hot: optimal housing temperatures for mice to mimic the thermal environment of humans. Molecular Metabolism 20122 5-9. (doi:10.1016/j.molmet.2012.10.002)

52 Porter C, Herndon DN, Chondronikola M, Chao T, Annamalai P, Bhattarai N, Saraf MK, Capek KD, Reidy PT, Daquinag AC, et al. Human and mouse brown adipose tissue mitochondria have comparable UCP1 function. Cell Metabolism 201624 246-255. (doi:10.1016/j.cmet.2016.07.004)

53 Lean ME, James WP, Jennings G \& Trayhurn P. Brown adipose tissue in patients with phaeochromocytoma. International Journal of Obesity $1986 \mathbf{1 0} 219-227$.

54 Frontini A, Vitali A, Perugini J, Murano I, Romiti C, Ricquier D, Guerrieri M \& Cinti S. White-to-brown transdifferentiation of omental adipocytes in patients affected by pheochromocytoma. Biochimica et Biophysica Acta 20131831 950-959. (doi:10.1016/j. bbalip.2013.02.005)

55 Sidossis LS, Porter C, Saraf MK, Borsheim E, Radhakrishnan RS, Chao T, Ali A, Chondronikola M, Mlcak R, Finnerty CC, et al. Browning of subcutaneous white adipose tissue in humans after severe adrenergic stress. Cell Metabolism 201522 219-227. (doi:10.1016/j.cmet.2015.06.022)

56 Skarulis MC, Celi FS, Mueller E, Zemskova M, Malek R, Hugendubler L, Cochran C, Solomon J, Chen C \& Gorden P. Thyroid hormone induced brown adipose tissue and amelioration of diabetes in a patient with extreme insulin resistance. Journal of Clinical Endocrinology and Metabolism 201095 256-262. (doi:10.1210/jc.2009-0543) 
57 Martinez-Sanchez N, Moreno-Navarrete JM, Contreras C, RialPensado E, Ferno J, Nogueiras R, Dieguez C, Fernandez-Real JM $\&$ Lopez M. Thyroid hormones induce browning of white fat. Journal of Endocrinology 2017232 351-362. (doi:10.1530/JOE-160425)

58 Chondronikola M, Volpi E, Borsheim E, Porter C, Annamalai P, Enerback S, Lidell ME, Saraf MK, Labbe SM, Hurren NM, et al. Brown adipose tissue improves whole-body glucose homeostasis and insulin sensitivity in humans. Diabetes 201463 4089-4099. (doi:10.2337/db14-0746)

59 Yoneshiro T, Aita S, Matsushita M, Kayahara T, Kameya T, Kawai Y, Iwanaga T \& Saito M. Recruited brown adipose tissue as an antiobesity agent in humans. Journal of Clinical Investigation 2013 123 3404-3408. (doi:10.1172/JCI67803)

60 Orava J, Nuutila P, Lidell ME, Oikonen V, Noponen T, Viljanen T, Scheinin M, Taittonen M, Niemi T, Enerback S, et al. Different metabolic responses of human brown adipose tissue to activation by cold and insulin. Cell Metabolism 201114 272-279. (doi:10.1016/j.cmet.2011.06.012)

61 Hanssen MJ, Hoeks J, Brans B, van der Lans AA, Schaart G, van den Driessche JJ, Jorgensen JA, Boekschoten MV, Hesselink MK, Havekes B, et al. Short-term cold acclimation improves insulin sensitivity in patients with type 2 diabetes mellitus. Nature Medicine 201521 863-865. (doi:10.1038/nm.3891)

62 Blondin DP, Labbe SM, Noll C, Kunach M, Phoenix S, Guerin B, Turcotte EE, Haman F, Richard D \& Carpentier AC. Selective impairment of glucose but not fatty acid or oxidative metabolism in brown adipose tissue of subjects with type 2 diabetes. Diabetes 201564 2388-2397. (doi:10.2337/db14-1651)

63 Blondin DP, Frisch F, Phoenix S, Guerin B, Turcotte EE, Haman F, Richard D \& Carpentier AC. Inhibition of intracellular triglyceride lipolysis suppresses cold-induced brown adipose tissue metabolism and increases shivering in humans. Cell Metabolism 201725 438-447. (doi:10.1016/j.cmet.2016.12.005)

64 Bartelt A, Bruns OT, Reimer R, Hohenberg H, Ittrich H, Peldschus K, Kaul MG, Tromsdorf UI, Weller H, Waurisch C, et al. Brown adipose tissue activity controls triglyceride clearance. Nature Medicine 201117 200-205. (doi:10.1038/nm.2297)

65 Schlein C, Talukdar S, Heine M, Fischer AW, Krott LM, Nilsson SK, Brenner MB, Heeren J \& Scheja L. FGF21 lowers plasma triglycerides by accelerating lipoprotein catabolism in white and brown adipose tissues. Cell Metabolism 201623 441-453. (doi:10.1016/j.cmet.2016.01.006)

66 Laurila PP, Soronen J, Kooijman S, Forsstrom S, Boon MR, Surakka I, Kaiharju E, Coomans CP, Van Den Berg SA, Autio A, et al. USF1 deficiency activates brown adipose tissue and improves cardiometabolic health. Science Translational Medicine 20168 $323 r a 313$.

67 Berbee JF, Boon MR, Khedoe PP, Bartelt A, Schlein C, Worthmann A, Kooijman S, Hoeke G, Mol IM, John C, et al. Brown fat activation reduces hypercholesterolaemia and protects from atherosclerosis development. Nature Communications 201566356. (doi:10.1038/ncomms7356)

68 Vijgen GH, Bouvy ND, Teule GJ, Brans B, Schrauwen P \& van Marken Lichtenbelt WD. Brown adipose tissue in morbidly obese subjects. PLOS ONE 20116 e17247. (doi:10.1371/journal. pone.0017247)

69 Matsushita M, Yoneshiro T, Aita S, Kameya T, Sugie H \& Saito M. Impact of brown adipose tissue on body fatness and glucose metabolism in healthy humans. International Journal of Obesity 201438 812-817. (doi:10.1038/ijo.2013.206)

70 Hanssen MJ, van der Lans AA, Brans B, Hoeks J, Jardon KM, Schaart G, Mottaghy FM, Schrauwen P \& van Marken Lichtenbelt WD. Short-term cold acclimation recruits brown adipose tissue in obese humans. Diabetes 201665 1179-1189. (doi:10.2337/db15-1372)
71 Villarroya F, Cereijo R, Villarroya J \& Giralt M. Brown adipose tissue as a secretory organ. Nature Reviews Endocrinology 201713 26-35. (doi:10.1038/nrendo.2016.136)

72 Gunawardana SC \& Piston DW. Reversal of type 1 diabetes in mice by brown adipose tissue transplant. Diabetes $2012 \mathbf{6 1}$ 674-682. (doi:10.2337/db11-0510)

73 Liu X, Zheng Z, Zhu X, Meng M, Li L, Shen Y, Chi Q, Wang $\mathrm{D}$, Zhang Z, Li C, et al. Brown adipose tissue transplantation improves whole-body energy metabolism. Cell Research 201323 851-854. (doi:10.1038/cr.2013.64)

74 Stanford KI, Middelbeek RJ, Townsend KL, An D, Nygaard EB, Hitchcox KM, Markan KR, Nakano K, Hirshman MF, Tseng $\mathrm{YH}$, et al. Brown adipose tissue regulates glucose homeostasis and insulin sensitivity. Journal of Clinical Investigation 2013123 215-223. (doi:10.1172/JCI62308)

75 Burysek L \& Houstek J. beta-Adrenergic stimulation of interleukin-1alpha and interleukin-6 expression in mouse brown adipocytes. FEBS Letters 1997411 83-86. (doi:10.1016/S00145793(97)00671-6)

76 Ikeda S, Tamura Y, Kakehi S, Sanada H, Kawamori R \& Watada H. Exercise-induced increase in IL-6 level enhances GLUT4 expression and insulin sensitivity in mouse skeletal muscle. Biochemical and Biophysical Research Communications 2016473 947-952. (doi:10.1016/j.bbrc.2016.03.159)

77 Mauer J, Chaurasia B, Goldau J, Vogt MC, Ruud J, Nguyen $\mathrm{KD}$, Theurich S, Hausen AC, Schmitz J, Bronneke HS, et al. Signaling by IL-6 promotes alternative activation of macrophages to limit endotoxemia and obesity-associated resistance to insulin. Nature Immunology 201415 423-430. (doi:10.1038/ni.2865)

78 Thomou T, Mori MA, Dreyfuss JM, Konishi M, Sakaguchi M, Wolfrum C, Rao TN, Winnay JN, Garcia-Martin R, Grinspoon $\mathrm{SK}$, et al. Adipose-derived circulating miRNAs regulate gene expression in other tissues. Nature $2017 \mathbf{5 4 2} 450-455$. (doi:10.1038/nature21365)

79 Chen Y, Buyel JJ, Hanssen MJ, Siegel F, Pan R, Naumann J, Schell M, van der Lans A, Schlein C, Froehlich H, et al. Exosomal microRNA miR-92a concentration in serum reflects human brown fat activity. Nature Communications 20167 11420. (doi:10.1038/ ncomms11420)

80 Cao H, Gerhold K, Mayers JR, Wiest MM, Watkins SM \& Hotamisligil GS. Identification of a lipokine, a lipid hormone linking adipose tissue to systemic metabolism. Cell $2008 \mathbf{1 3 4}$ 933-944. (doi:10.1016/j.cell.2008.07.048)

81 Yore MM, Syed I, Moraes-Vieira PM, Zhang T, Herman MA, Homan EA, Patel RT, Lee J, Chen S, Peroni OD, et al. Discovery of a class of endogenous mammalian lipids with anti-diabetic and anti-inflammatory effects. Cell 2014159 318-332. (doi:10.1016/j. cell.2014.09.035)

82 Lynes MD, Leiria LO, Lundh M, Bartelt A, Shamsi F, Huang TL, Takahashi H, Hirshman MF, Schlein C, Lee A, et al. The coldinduced lipokine 12,13-diHOME promotes fatty acid transport into brown adipose tissue. Nature Medicine 201723 631-637. (doi:10.1038/nm.4297)

83 Boon MR, Bakker LE, Prehn C, Adamski J, Vosselman MJ, Jazet IM, Arias-Bouda LM, van Lichtenbelt WD, van Dijk KW, Rensen PC, et al. LysoPC-acyl C16:0 is associated with brown adipose tissue activity in men. Metabolomics 201713 48. (doi:10.1007/ s11306-017-1185-z)

84 Hondares E, Iglesias R, Giralt A, Gonzalez FJ, Giralt M, Mampel T \& Villarroya F. Thermogenic activation induces FGF21 expression and release in brown adipose tissue. Journal of Biological Chemistry 2011286 12983-12990. (doi:10.1074/jbc.M110.215889)

85 Gimeno RE \& Moller DE. FGF21-based pharmacotherapy potential utility for metabolic disorders. Trends in 
Endocrinology and Metabolism 201425 303-311. (doi:10.1016/j. tem.2014.03.001)

86 von Holstein-Rathlou S, BonDurant LD, Peltekian L, Naber MC, Yin TC, Claflin KE, Urizar AI, Madsen AN, Ratner C, Holst B, et al. FGF21 mediates endocrine control of simple sugar intake and sweet taste preference by the liver. Cell Metabolism 201623 335-343. (doi:10.1016/j.cmet.2015.12.003)

87 Talukdar S, Owen BM, Song P, Hernandez G, Zhang Y, Zhou Y, Scott WT, Paratala B, Turner T, Smith A, et al. FGF21 regulates sweet and alcohol preference. Cell Metabolism 201623 344-349. (doi:10.1016/j.cmet.2015.12.008)

88 Hanssen MJ, Broeders E, Samms RJ, Vosselman MJ, van der Lans AA, Cheng CC, Adams AC, van Marken Lichtenbelt WD \& Schrauwen P. Serum FGF21 levels are associated with brown adipose tissue activity in humans. Scientific Reports $2015 \mathbf{5} 10275$. (doi:10.1038/srep10275)

89 Lee P, Linderman JD, Smith S, Brychta RJ, Wang J, Idelson C, Perron RM, Werner CD, Phan GQ, Kammula US, et al. Irisin and FGF21 are cold-induced endocrine activators of brown fat function in humans. Cell Metabolism 201419 302-309. (doi:10.1016/j.cmet.2013.12.017)

90 Gaich G, Chien JY, Fu H, Glass LC, Deeg MA, Holland WL, Kharitonenkov A, Bumol T, Schilske HK \& Moller DE. The effects of LY2405319, an FGF21 analog, in obese human subjects with type 2 diabetes. Cell Metabolism 201318 333-340. (doi:10.1016/j. cmet.2013.08.005)

91 Talukdar S, Zhou Y, Li D, Rossulek M, Dong J, Somayaji V, Weng Y, Clark R, Lanba A, Owen BM, et al. A long-acting FGF21 molecule, PF-05231023, decreases body weight and improves lipid profile in non-human primates and type 2 diabetic subjects. Cell Metabolism 201623 427-440. (doi:10.1016/j.cmet.2016.02.001)

92 Geloen A, Collet AJ, Guay G \& Bukowiecki LJ. Beta-adrenergic stimulation of brown adipocyte proliferation. American Journal of Physiology 1988254 C175-C182.

93 Collins S, Daniel KW, Petro AE \& Surwit RS. Strain-specific response to beta 3-adrenergic receptor agonist treatment of diet-induced obesity in mice. Endocrinology 1997138 405-413. (doi:10.1210/endo.138.1.4829)

94 Cao W, Medvedev AV, Daniel KW \& Collins S. beta-Adrenergic activation of $\mathrm{p} 38$ MAP kinase in adipocytes: cAMP induction of the uncoupling protein 1 (UCP1) gene requires p38 MAP kinase. Journal of Biological Chemistry 2001276 27077-27082. (doi:10.1074/jbc.M101049200)

95 Cypess AM, Chen YC, Sze C, Wang K, English J, Chan O, Holman AR, Tal I, Palmer MR, Kolodny GM, et al. Cold but not sympathomimetics activates human brown adipose tissue in vivo. PNAS 2012109 10001-10005. (doi:10.1073/pnas.1207911109) Cypess AM, Weiner LS, Roberts-Toler C, Franquet Elia E, Kessler SH, Kahn PA, English J, Chatman K, Trauger SA, Doria A, et al.
Activation of human brown adipose tissue by a beta3-adrenergic receptor agonist. Cell Metabolism 201521 33-38. (doi:10.1016/j. cmet.2014.12.009)

97 Baskaran P, Krishnan V, Ren J \& Thyagarajan B. Capsaicin induces browning of white adipose tissue and counters obesity by activating TRPV1 channel-dependent mechanisms. British Journal of Pharmacology 2016173 2369-2389. (doi:10.1111/bph.13514)

98 Pi-Sunyer X, Astrup A, Fujioka K, Greenway F, Halpern A, Krempf M, Lau DC, le Roux CW, Violante Ortiz R, Jensen CB, et al. A randomized, controlled trial of $3.0 \mathrm{mg}$ of liraglutide in weight management. New England Journal of Medicine 2015373 11-22. (doi:10.1056/nejmoa1411892)

99 Burcelin R \& Gourdy P. Harnessing glucagon-like peptide-1 receptor agonists for the pharmacological treatment of overweight and obesity. Obesity Reviews 201718 86-98. (doi:10.1111/obr.12465)

100 Beiroa D, Imbernon M, Gallego R, Senra A, Herranz D, Villarroya F, Serrano M, Ferno J, Salvador J, Escalada J, et al. GLP-1 agonism stimulates brown adipose tissue thermogenesis and browning through hypothalamic AMPK. Diabetes 201463 3346-3358. (doi:10.2337/db14-0302)

101 Teodoro JS, Zouhar P, Flachs P, Bardova K, Janovska P, Gomes AP, Duarte FV, Varela AT, Rolo AP, Palmeira CM, et al. Enhancement of brown fat thermogenesis using chenodeoxycholic acid in mice. International Journal of Obesity 201438 1027-1034. (doi:10.1038/ ijo.2013.230)

102 Broeders EP, Nascimento EB, Havekes B, Brans B, Roumans KH, Tailleux A, Schaart G, Kouach M, Charton J, Deprez B, et al. The bile acid chenodeoxycholic acid increases human brown adipose tissue activity. Cell Metabolism 201522 418-426. (doi:10.1016/j. cmet.2015.07.002

103 Watanabe M, Houten SM, Mataki C, Christoffolete MA, Kim BW, Sato H, Messaddeq N, Harney JW, Ezaki O, Kodama T, et al. Bile acids induce energy expenditure by promoting intracellular thyroid hormone activation. Nature 2006439 484-489. (doi:10.1038/nature04330)

104 Tseng YH, Kokkotou E, Schulz TJ, Huang TL, Winnay JN, Taniguchi CM, Tran TT, Suzuki R, Espinoza DO, Yamamoto Y, et al. New role of bone morphogenetic protein 7 in brown adipogenesis and energy expenditure. Nature $2008 \mathbf{4 5 4}$ 1000-1004. (doi:10.1038/nature07221)

105 Whittle AJ, Carobbio S, Martins L, Slawik M, Hondares E, Vazquez MJ, Morgan D, Csikasz RI, Gallego R, Rodriguez-Cuenca S, et al. BMP8B increases brown adipose tissue thermogenesis through both central and peripheral actions. Cell 2012149 871-885. (doi:10.1016/j.cell.2012.02.066)

106 Modica S \& Wolfrum C. Bone morphogenic proteins signaling in adipogenesis and energy homeostasis. Biochimica et Biophysica Acta 20131831 915-923. (doi:10.1016/i.bbalip.2013.01.010)

Received in final form 17 April 2017

Accepted 2 May 2017

Accepted Preprint published online 2 May 2017 http://www.endocrineconnections.org DOI: 10.1530/EC-17-0037
() 2017 The authors Published by Bioscientifica Ltd

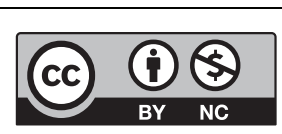

This work is licensed under a Creative Commons Attribution-NonCommercial 4.0 International License. 